\title{
Analysis of enamel and material wear by digital microscope: an in-vitro study. Braz Oral Res. 2019;33:e121. https://doi.org/10.1590/1807- 3107bor-2019.vol33.0121
}

Corresponding Author e-mail

Where is read: rashidhabib@hotmail.com

It should read: syhabib@ksu.edu.sa 